\title{
Evaluation of initial attachment of human gingival fibroblast cells to biodegradable membranes in vitro by light and scanning electron microscopy
}

\author{
Berrin Ünsal, Gönen Özcan, Gülay Tüter, Bülent Kurtiş and Mehmet Yalım \\ Department of Periodontology, Faculty of Dentistry, Gazi University, Ankara, Turkey
}

(Received 15 December 1998 and accepted 13 April 1999)

\begin{abstract}
Guided tissue regeneration procedures using resorbable membranes have become accepted therapy for treating periodontal defects. Resorbable collagen and synthetic polylactide and polyglycolide copolymer membranes have been found to support regeneration and preclude the need for surgical removal. This study was undertaken to assess and compare the initial attachment of human gingival fibroblast cells to four collagen-based membranes (fascia lata, fascia temporalis, dura mater, and Type I bovine collagen) and a synthetic polylactic acid-based membrane (resolut ${ }^{\circledR}$ ). Human gingival fibroblasts were grown from explants of normal tissue obtained during surgical reduction of retromolar tissues. Membrane specimens were placed in separate culture wells and incubated with fibroblasts for one hour. The number of adherent cells was evaluated by light microscopy using an ocular grid system and detailed examination was performed by scanning electron microscopy. The results of evaluation by light microscopy indicated that initial cell attachment was significantly less in the polylactic acid-based membrane group than in the collagen-based membrane groups $(P<0.01)$. However, no significant differences were found among the collagen membrane groups in terms of fibroblast attachment $(P>0.01)$. Scanning electron microscopy examination of fibroblasts cultured directly on barrier membranes indicated that the collagen-based membranes appeared to facilitate cell attachment, whereas the polylactic acid-based membrane exhibited a morphology that was not conducive to attachment of human gingival fibroblasts. Based on these limited in vitro results, it appears that collagen-based membranes offer greater potential than polylactic acid-based membranes for guided tissue regeneration at surgical sites. (J. Oral Sci. 41, 57-60, 1999)
\end{abstract}

Key words: Fibroblast; initial attachment; biodegradable membranes; guided tissue regeneration.

Correspondence to Associate Professor Berrin Ünsal, Gazi Üniversitesi Dişhekimliği Fakültesi, Periodontoloji Anabilim Dalı, Emek Mah. Bişkek Cad. 82. Sok., 06510 Ankara, Turkey

\section{Introduction}

The primary goal of the guided tissue regeneration (GTR) technique is to provide predictable regeneration of the periodontium by allowing repopulation of periodontal ligament cells onto exposed root surfaces, preventing ingrowth of gingival connective tissue and epithelial cells (1-4). A variety of resorbable and non-resorbable barrier membranes have been utilized as regenerative materials based on the principles of GTR. To avoid a second surgical operation solely for removal of non-resorbable membranes, several resorbable membranes have been developed, of which collagen and polylactic acid membranes have shown promising results (510).

Collagen is the most important structural protein component of the human body and an essential constituent of the periodontium for maintaining organic union between the bone and the teeth (11). In vitro experiments have determined that human gingival and periodontal ligament fibroblasts show continued growth on collagen materials $(11,12)$. Recently, therefore most emphasis has been placed on the use of collagenbased membranes.

In cases where primary wound closure over a barrier membrane is not possible, cellular attachment to and migration over the barrier surface are critical to achieving wound closure and flap stabilization (13). The aim of the present study was to examine the ability of human gingival fibroblast (HGF) cells in vitro to produce initial attachment to five GTR membrane materials. Obviously, it is highly desirable to find a membrane barrier that can facilitate both osseous regeneration and migration of connective tissue cells to effect complete closure of overlying soft tissue defects.

\section{Materials and Methods}

Solvent-dried collagen-based membranes fascia lata, fascia temporalis, and dura mater were of human origin (Tutoplast, Biodynamics, Erlangen, Germany), and highly cross-linked Type I absorbable collagen membranes were of bovine origin (CollaTec, Inc., Plainsboro, NJ, USA). The polylactic/polyglycolide acid (PLA/PGA) copolymer was resolut ${ }^{\circledR}$ (Gore-Tex ${ }^{\circledR}$ Regenerative Materials, Flagstaff, AZ, USA). All were obtained commercially 


\section{Cell Culture}

Fibroblasts were obtained from explant cultures of healthy human gingival tissues that were excised from retromolar gingiva during retromolar surgery. Gingival tissues were minced into small pieces (less than $0.5 \mathrm{~mm}$ ), then plated and cultured according to the procedure described by Brunette et al. (14). Dulbecco's Modified Eagle Medium (DMEM) (Sigma, St. Louis, MO, USA) containing $15 \%$ fetal calf serum (FCS) and $100 \mu \mathrm{g} / \mathrm{ml}$ penicillin, $100 \mu \mathrm{g} / \mathrm{ml}$ streptomycin, $50 \mu \mathrm{g} / \mathrm{ml}$ gentamycin and $2.5 \mathrm{mg} / \mathrm{ml}$ amphotericin B (Fungizone) was used for cell culture. Cells were cultured in a humidified atmosphere of $5 \% \mathrm{CO}_{2}$ in air at $37^{\circ} \mathrm{C}$ until confluent monolayers were obtained. In the culture wells, old medium was replaced with fresh medium every 3 to 4 days for 1 week. Fibroblasts were separated for subculture with $0.25 \%$ trypsin. Upon reaching confluence after about two weeks, coverslips were removed and the cultures dispersed with $0.25 \%$ trypsin and Dulbecco salt solution, $\mathrm{pH} 7.3$, into plastic tissue culture flasks. After the sixth passage cells were frozen at $-70^{\circ} \mathrm{C}$.

\section{Cell Attachment}

The 24 membrane specimens were placed in separate culture wells (Linbro plate) and incubated with $2.8 \times 10^{5}$ cells in 1 $\mathrm{ml}$ of DMEM in a humidified atmosphere of $95 \%$ air and 5 $\% \mathrm{CO}_{2}$ for $1 \mathrm{~h}$ at $37^{\circ} \mathrm{C}$. Unattached cells were resuspended every $15 \mathrm{~min}$ during the incubation period. After $1 \mathrm{~h}$ the membrane specimens were transferred to fresh wells, washed twice with phosphate buffered saline (PBS) and stained with Giemsa. Four samples of each membrane type were analysed by light microscopy (Olympus Vanox) for adhesion of human gingival fibroblasts. The number of attached cells per unit area was determined by an ocular grid $(10 \times 10 \mathrm{~mm})$ system at a magnification of $\times 100$. Quantitative results for each membrane specimens were obtained from four randomly chosen areas.

Two specimens from each membrane group were processed for evaluation by scanning electron microscopy (SEM). The cultures were rinsed in sucrose containing cacodylate buffer, fixed in $0.1 \mathrm{M}$ cacodylate buffer containing $2 \%$ glutaraldehyde, post-fixed in $1 \%$ osmium tetroxide for $1 \mathrm{~h}$, dehyrated in an ethanol series, critical point dried and coated with gold (Leitz AMR). They were then observed using low-temperature SEM (JEOL JSM 6400).

Statistical significance of differences in cell attachment was determined by analysis of variance and the Duncan multiple range test.

\section{Results \\ Light Microscopy Observations}

Statistical comparisons of the mean number of HGF cells attached to the membranes during $1 \mathrm{~h}$ are shown in Table 1. These measurements indicated significantly less initial cell attachment in the resolut ${ }^{\circledR}$ group than in the other membrane groups $(\mathrm{P}<0.01)$. However, no significant differences were found among the collagen-based membrane groups $(\mathrm{P}>0.01)$. These cells were found to be not only attached, but in the process of spreading.
Table 1 Comparison of the mean number of cells on biodegradable membranes

\begin{tabular}{lc}
\hline \multicolumn{1}{c}{ Membrane groups } & Mean \pm SD \\
\hline Fascia lata $(n=4)$ & $21.75 \pm 0.26$ \\
\hline Type I collagen barrier $(n=4)$ & $21.35 \pm 0.49$ \\
\hline Fascia temporalis $(n=4)$ & $21.25 \pm 0.64$ \\
\hline Dura mater $(n=4)$ & $22.55 \pm 0.46$ \\
\hline Resolut ${ }^{\otimes}(n=4)$ & $12.80 \pm 0.47^{*}$ \\
\hline$P<0.01$.
\end{tabular}

\section{SEM Observations}

Examination of the cultures by SEM showed the morphological characteristics of HGF cells and their attachment to the collagen and PLA membranes at $1 \mathrm{~h}$. The HGF cells which adhered to the membranes showed variations in shape and size, however, no apparent differences were observed in the morphology of cells. The majority of cells cultured on the membranes showed a rounded morphology (Fig. 1:A1, A2, B1, B2, C1, C2, D1, D2, E1 and E2).

In the collagen-based membrane groups, the collagen fibers created mesh-like networks that overlapped each other (Fig. 1:A1, B1, C1 and D1). However, the surface texture of the membrane created in the PLA group consisted of solid fibers.

In some of the attached cells, the cytoplasmic processes were prominent, and appeared to mediate the adhesion of the cells to the membrane specimens (Fig. 1:A1 and A2).

\section{Discussion}

The results of this in vitro experiment showed that collagenand PLA/PGA-based membranes were biocompatible for the initial attachment of HGF, but that the mean number of cells was greater over the surface of collagen-membrane barriers compared with those over the PLA/PGA membrane group.

Barrier membranes were used routinely in early GTR procedures and appear to have been ideally suited in cases where primary closure could be obtained over the wound site. However, primary wound closure is not always possible. Furthermore, even under ideal circumstances, injury to the gingiva is common during the healing phase. When recession does occur over a barrier, infection by pathogenic bacteria is likely to occur, and may result in a decreased regenerative response. If primary wound closure is not possible over membrane material, cellular attachment, especially HGF cell attachment, to the membrane surface is important in achieving wound closure (15).

Cellular attachment to the membrane-like substrate surface depends upon such intrinsic and extrinsic factors as the intracellular components of HGF and the physico-chemical nature of the membrane substrate (16). Thus, the biomaterial characteristics and design of membranes may play an important role in the attachment of fibroblasts. Resolut ${ }^{\circledR}$ membrane consists of an occlusive film with a bonded, randomly-oriented fiber matrix on each surface (4). This random organization 


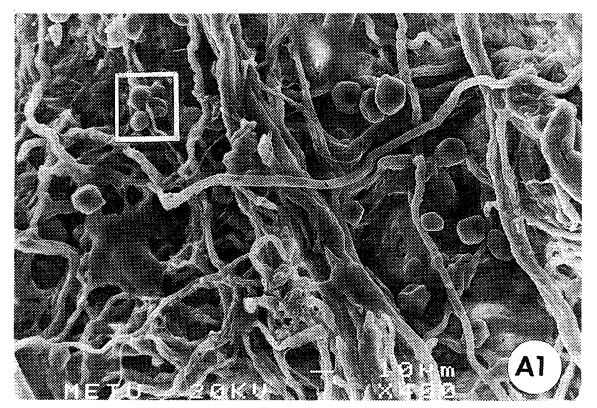

Fig. 1:A1 Fascia lata, original magnification $\times 400$

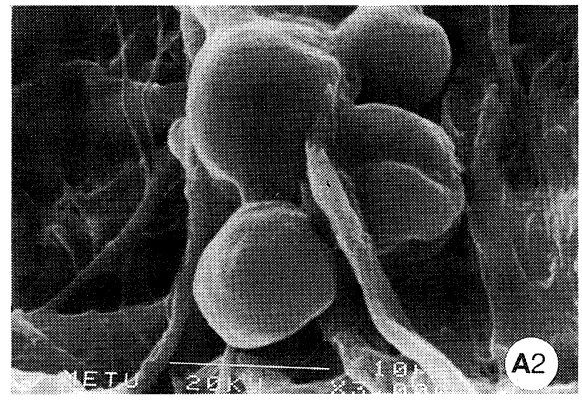

Fig. 1:A2 Fascia lata, original magnification $\times 3000$

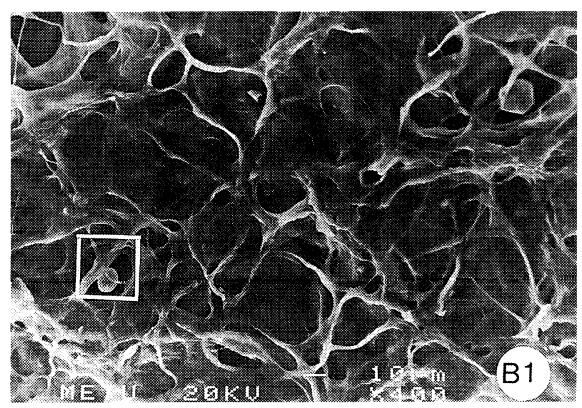

Fig. 1:B1 Type I collagen barrier, original magnification $\times 400$

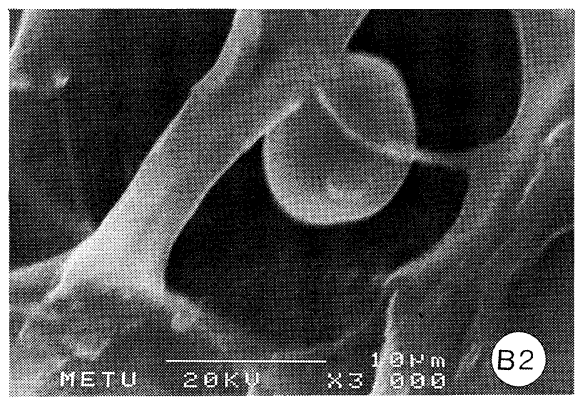

Fig. 1:B2 Type I collagen barrier, original magnification $\times 3000$

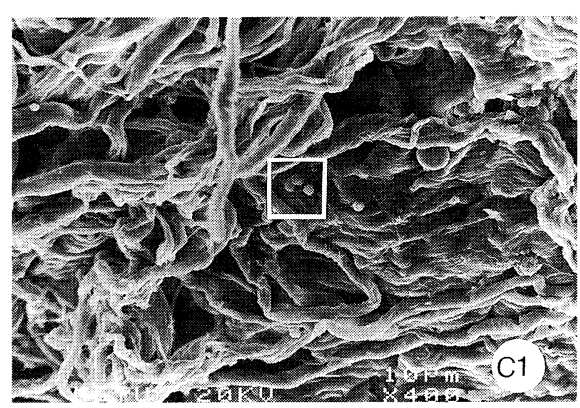

Fig. 1:C1 Fascia temporalis, original magnification $\times 400$

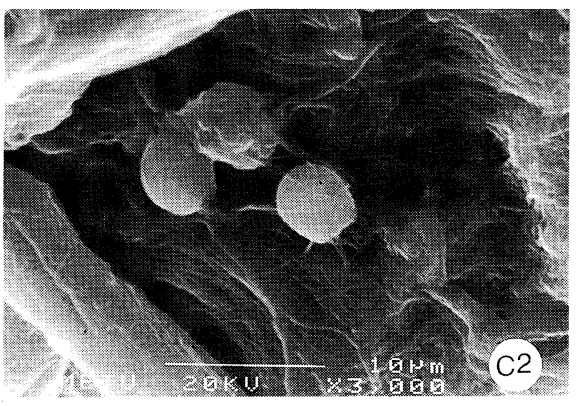

Fig. 1:C2 Fascia temporalis, original magnification $\times 3000$

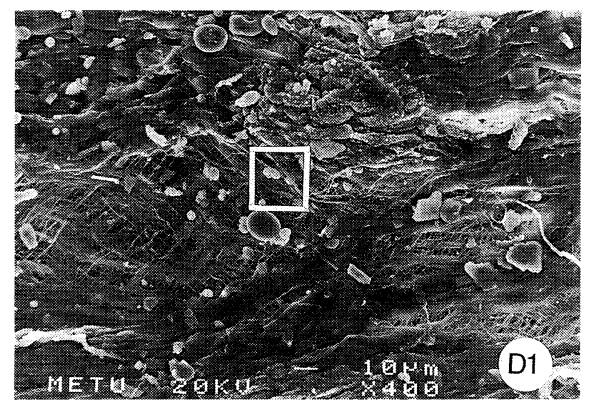

Fig. 1:D1 Dura mater, original magnification $\times 400$

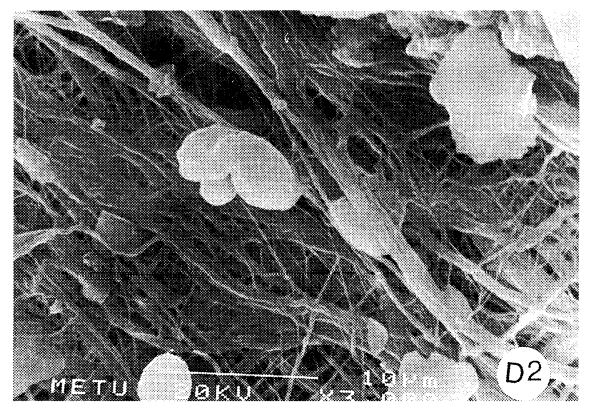

Fig. 1:D2 Dura mater, original magnification $\times 3000$

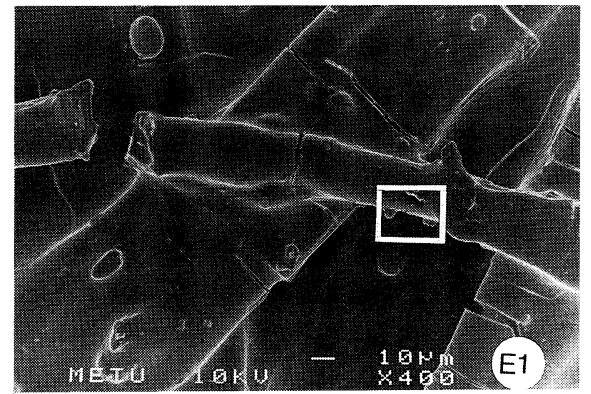

Fig. 1:E1 Resolut ${ }^{\circledR}$, original magnification $\times 400$

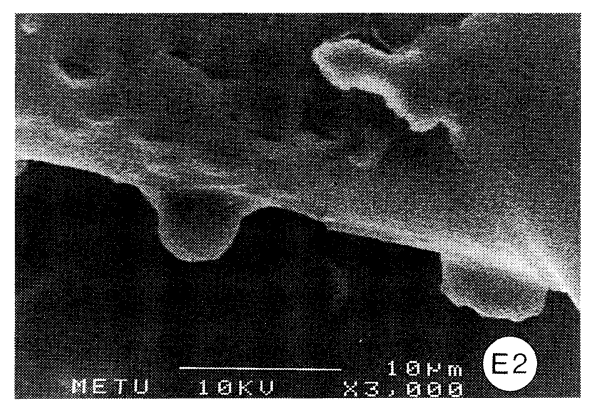

Fig. 1:E2 Resolut ${ }^{\circledR}$, original magnification $\times 3000$ 
of the membrane structure may decrease the attachment potential of fibroblasts. The structure of collagen-based membranes may allow more rapid attachment of fibroblast cells.

In a previous study, Payne et al. (15) used SEM to evaluate the ability of HGF cells in vitro to migrate along chemotactic gradients over three different GTR barrier materials: expanded polytetrafluoroethylene (ePTFE), polylactic acid and calcium sulfate. They showed that the mean migration distance over calcium sulfate was significantly greater than that over the polylactic acid membrane. The present study indicated that the calcium sulfate substrate appeared to facilitate cell attachment and spreading, and polylactic acid membranes exhibited a morphology that was not conducive to migration.

Finally, in vivo wound healing involves the interaction of a variety of cell types, including mesenchymal, hematological and inflammatory cells; however, only gingival fibroblast cells were examined in the present study. In addition, most in vitro models do not consider the influence of growth factors derived from blood and blood clots.

Further research is now necessary to evaluate the organization of fibroblast cells on these resorbable membranes.

\section{Acknowledgments}

The authors gratefully acknowledge the assistance of Dr. Ismet Gürhan of the Foot and Mouth Disease Institute in maintaining cell cultures.

\section{References}

1. Nyman, S., Lindhe, J., Karring, T. and Rylander, H. (1982) New attachment following surgical treatment of human periodontal disease. J. Clin. Periodontol. 9, 290-296

2. Caffesse, R.G. and Becker, W. (1991) Principles and techniques of guided tissue regeneration. Dent. Clin. North. Am. 35, 479-494

3. Tanner, M.G., Solt, C.W. and Vuddhakanok, S. (1988) An evaluation of new attachment formation using a microfibrillar collagen barrier. J. Periodontol. 59, 524530

4. Hardwick, R., Hayes, B.K. and Flynn, C. (1995) Devices for dentoalveolar regeneration: An up-to-date literature review. J. Periodontol. 66, 495- 505

5. Magnusson, I., Batich, C. and Collins, B.R. (1988) New attachment formation following controlled tissue regeneration using biodegradable membranes. J.
Periodontol. 59, 1-6

6. Gottlow, J. (1993) Guided tissue regeneration using bioresorbable and non-resorbable devices: initial healing and long-term results. J. Periodontol. 64, 1157-1165

7. Vuddhakanok, S., Solt, C.W., Mitchell, J.C., Foreman, D.W. and Alger, F.A. (1993) Histologic evaluation of periodontal attachment apparatus following the insertion of a biodegradable copolymer barrier in humans. J. Periodontol. 64, 202-210

8. Robert, P., Mauduit, J., Frank, R.M. and Vert, M. (1993) Biocompatibility and resorbability of a polylactic acid membrane for periodontal guided tissue regeneration. Biomaterials 14, 353-358

9. Chung, K.M., Salkin, L.M., Stein, M.D. and Freedman, A.L. (1990) Clinical evaluation of a biodegradable collagen membrane in guided tissue regeneration. $\mathbf{J}$. Periodontol. 61, 732-736

10. Quteish, D. and Dolby, A.E. (1992) The use of irradiated, crosslinked human collagen membrane in guided tissue regeneration. J. Clin. Periodontol. 19, 476-484

11. Hyder, P.R., Dowell, P., Singh, G. and Dolby, A.E. (1992) Freeze-dried, cross-linked bovine Type I collagen: analysis of properties. J. Periodontol. 63, 182-186

12. Quteish, D., Singrao, S. and Dolby, A.E. (1991) Light and electron microscopic evaluation of biocompatibility, resorption and penetration characteristics of human collagen graft material. J. Clin. Periodontol. 18, 305311

13. Brunette, D.M. (1988) The effects of implant surface topography on the behavior of cells. Int. J. Oral Maxillofac. Implants 3, 231-246

14. Brunette, D.M., Melcher, A.H. and Moe, H.K. (1976) Culture and origin of epithelium-like and fibroblast-like cells from porcine periodontal ligament explants and cell suspensions. Arch. Oral. Biol. 21, 393-400

15. Payne, J.M., Cobb, C.M., Rapley, J.W., Killoy, W.J. and Spencer, P. (1996) Migration of human gingival fibroblasts over guided tissue regeneration barrier materials. J. Periodontol. 67, 236-244

16. Burridge, K. (1986) Substrate adhesions in normal and transformed fibroblasts: organization and regulation of cytoskeletal, membrane and extracellular matrix components at focal contacts. Cancer Rev. 4, 18-78 